\title{
Seismic and petrophysical properties of Faroe Islands basalts: the SeiFaBa project
}

\author{
Peter Japsen, Morten Sparre Andersen, Lars Ole Boldreel, Regin Waagstein, Robert S. White \\ and Michael Worthington
}

Flood basalt-covered basins exist worldwide along continental margins and are now in focus as targets for future hydrocarbon exploration. It is generally difficult to image through the basalt cover by conventional seismic reflection methods, and this is a major challenge to future petroleum exploration offshore the Faroe Islands. Long-offset profiling has proven very successful (White et al. 2003). Surprisingly, however, it is possible to image through kilometre-thick basalt sequences on some conventional profiles. Details of basalt stratigraphy are revealed on old, reprocessed seismic profiles as well as on recently acquired profiles, even though the imaging may be unsuccessful on nearby profiles (e.g. Boldreel \& Andersen 1993). This stresses the need for a better understanding of the acoustic and other physical properties of basalt as well as of the degree of three-dimensional heterogeneity. The SeiFaBa project (Seismic and petrophysical properties of Faroes Basalt, 2002-2005) is funded by the Sindri Group as part of the programmes for licensees within the Faroese offshore area, and addresses these issues with special focus on the subaerially extruded flood basalts of the Faroe Islands (cf. Japsen et al. in press).
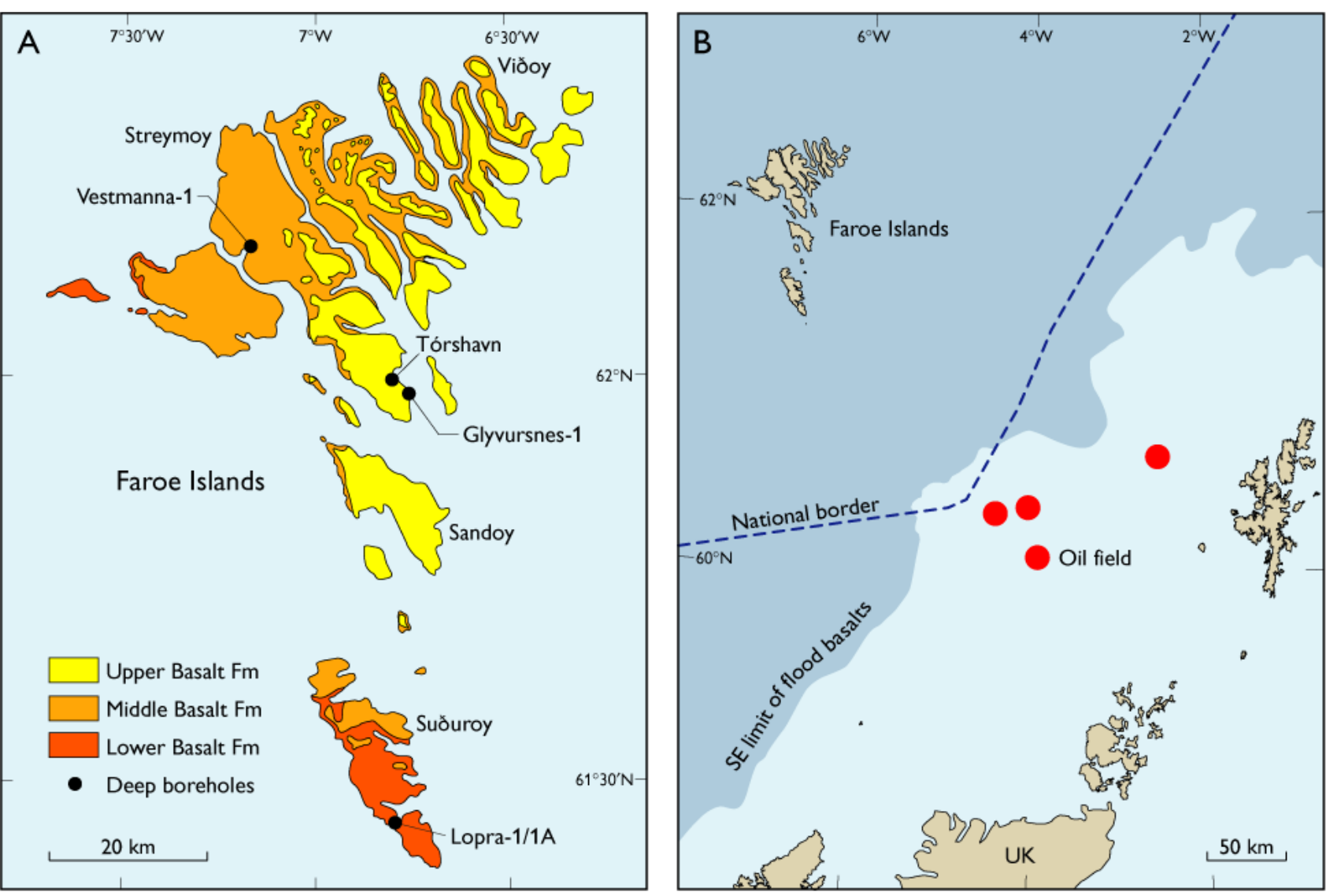

Fig. 1. A: Geological map of the Faroe Islands showing the location of deep boreholes and the distribution of the three Palaeogene basalt formations (modified from Waagstein 1998). B: Location of the Faroe Islands relative to the extent of flood basalts and producing oil fields (modified from Grant et al. 1999; Sørensen 2003). 


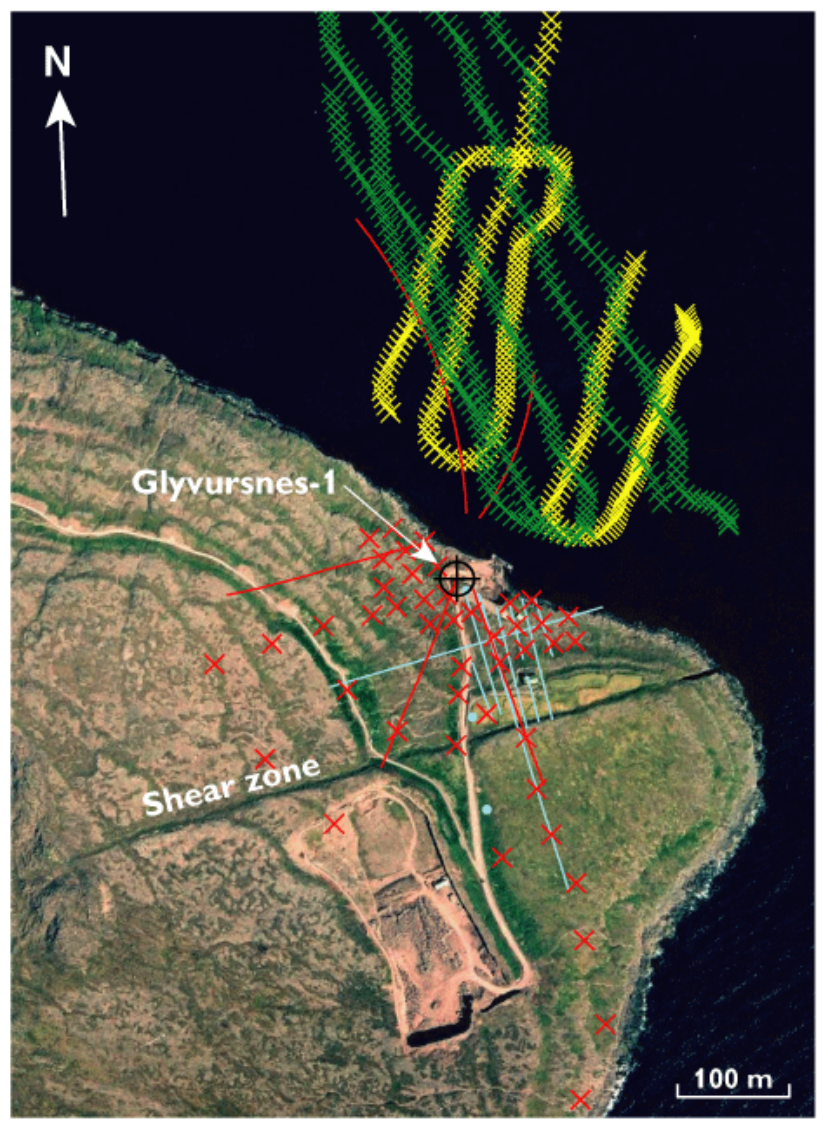

Fig. 2. Aerial photograph of Glyvursnes with well location and outline of seismic data recording on Glyvursnes in 2003. Red crosses indicate the locations of permanent seismometers during the experiments. Blue dots mark the positions of the three airgun pits for the VSP experiments. Blue lines mark the locations of the $14 \mathrm{~Hz}$ geophone strings used for the onshore reflection profiles. Red lines show the locations of onshore geophone strings and the tethered streamer during the offshore-onshore experiments and marine reflection experiment. Yellow and green crosses mark shotpoints for the marine reflection experiment (from Japsen et al. in press).

\section{Drilling and logging at Glyvursnes and Vestmanna}

The Glyvursnes-1 well was drilled outside Tórshavn to 700 $\mathrm{m}$ as a slim borehole with wire-line coring technique as part of the SeiFaBa project in 2002 (Fig. 1; Waagstein et al. 2003). Glyvursnes is well suited for combining vertical seismic profiles (VSP) and surface seismic experiments (onshore and offshore): the terrain is relatively flat and the seismic effects of a nearby near-vertical shear zone can be studied in detail (Fig. 2). During the same operations, the existing $660 \mathrm{~m}$ deep Vestmanna-1 well was reamed and logged. Three deep wells on the Faroe Islands have drilled thick sections of the Lower, Middle and Upper Basalt Formations (Fig. 3; Rasmussen \& Noe-Nygaard 1970):
1. The Vestmanna-1 well was drilled to $660 \mathrm{~m}$ in 1980 and reopened to $590 \mathrm{~m}$ in 2002 and logged. The hole was drilled in the lower part of the Middle Basalt Formation and extends $100 \mathrm{~m}$ into the Lower Basalt Formation. A full core was taken.

2. The Lopra-1/1A well was drilled through the Lower Basalt Formation to $2.2 \mathrm{~km}$ in 1981 , and deepened to $3.6 \mathrm{~km}$ in 1996 without reaching the base of the volcanic succession. One short core of basalt was taken from this well.

3. The Glyvursnes-1 well was drilled to $700 \mathrm{~m}$ in 2002 to around the boundary between the Middle and Upper Basalt Formations (Fig. 4). A full core was taken.

An extensive logging programme was run in the Glyvursnes and Vestmanna boreholes, comparable to that previously run in the Lopra well in 1981 and 1996. The programme includes optical televiewer, caliper, natural gamma ray, resistivity, neutron porosity, density, full wave sonic, spectral gamma (of poor quality) and temperature/conductivity measurements.

The Vestmanna and Glyvursnes boreholes penetrate, respectively, the lowermost $550 \mathrm{~m}$ and the uppermost $450 \mathrm{~m}$ of the $1400 \mathrm{~m}$ thick Middle Basalt Formation. In both sections the Middle Basalt Formation is characterised by the presence of plagioclase-phyric compound flows composed of thin flow-units of variable porosity, and by rare thin beds of tuff. The lowermost part of the Middle Basalt Formation in the Vestmanna borehole and the lowermost $70 \mathrm{~m}$ of the Upper Basalt Formation in the Glyvursnes borehole are very similar. The overlying section at about 230 to $285 \mathrm{~m}$ in Glyvursnes-1 consists of a few relatively thick plagioclasephyric flow-units possibly forming two compound flows (the Tórshavn flows), that are morphologically very similar to the flows of the Lower Basalt Formation (except that the latter are near-aphyric).

\section{Future work}

Ultrasonic velocities and other parameters will be measured on core samples from selected drill holes. The samples will be investigated under varying pressure for both dry and saturated samples. Studies of the velocity-porosity relationships of basalts will focus on matrix properties, but will also take into account variations in magma type, secondary mineralisation, pore shapes and fractures.

A lithostratigraphic interpretation of the borehole logs will be carried out, and the results will be correlated with petrography, rock chemistry and ultrasonic properties of core samples. This comparison of data acquired at core and log scale will be extended to data of seismic scale acquired from flood basalts of all three formations. Well log and core data 
Fig. 3. Stratigraphical position of deep boreholes in the Faroe Islands (modified from Waagstein 1988). See Fig. 1 for location of wells.

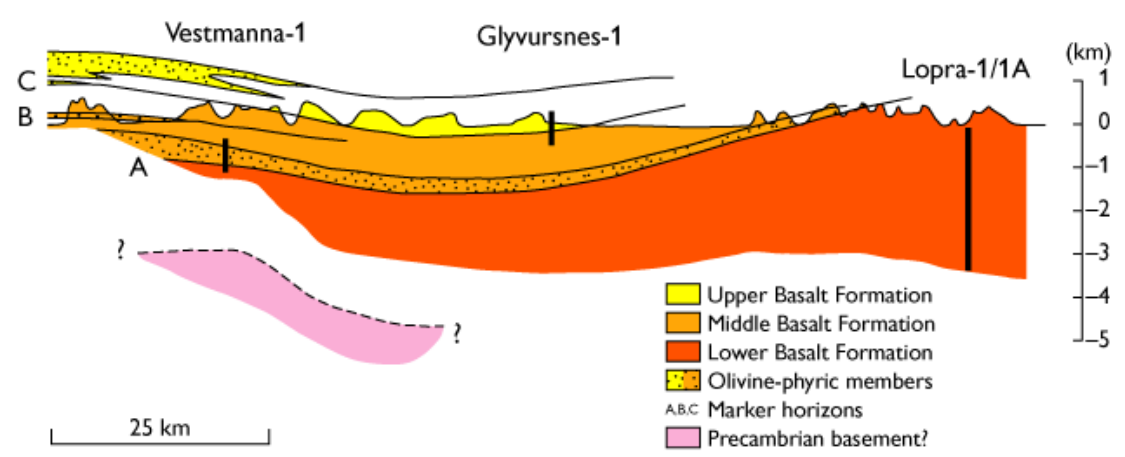

will be examined to evaluate how magma type and secondary mineralisation influence the relationships between velocity and porosity of basalt. Supplementary analysis of well logs from exploration wells in the Faroe-Shetland Basin will be carried out to provide additional data concerning the distribution of elastic properties of the basalts around the Faroe Islands.

\section{Seismic experiments at Glyvursnes}

The extrusive basalt flows in the Faroe-Shetland Basin are generally sub-horizontal on a regional scale, although there are often large physical property variations (largely governed by porosity) within individual flows, and locally rugged small-scale relief on the tops of flows. The strong layering and local relief may cause internal multiples, forward- and backscattering of the incident energy, multiple-mode conversion, anisotropy, absorption and geometric spreading, and lowpass filtering of the energy that propagates through a stacked layer of basalt flows.

Since flow thicknesses are at least an order of magnitude smaller than the seismic wavelength, reflections are rarely seen from individual flows: the seismic response depends on the complex interactions of reflections from multiple flow units. To study these effects, three closely integrated seismic experiments were carried out around the Glyvursnes-1 borehole in 2003 (Fig. 2).

Three VSP surveys were undertaken with source offsets of 14, 242 and $415 \mathrm{~m}$. The two offset locations were on either side of a well-defined shear zone.

Onshore and offshore high resolution data were acquired along the lines shown in Fig. 2. Two $625 \mathrm{~m}$ lines were shot with the charges along the line, while short profiles were acquired with the source displaced laterally. The marine seismic reflection data were acquired on a tethered streamer using a moving airgun cluster. Additional data were obtained at longer offsets.
A dense array of 45 autonomous seismometers was deployed for a six-month period around the site of the borehole. During periods of controlled source seismic shooting, all sites maintained a sampling rate of 200 samples/sec. For intervening periods, when recording earthquakes, a sampling rate of 100 samples/sec was used. In addition, three $400 \mathrm{~m}$ long independent temporary land arrays were set up in September 2003 using a mixture of one- and three-component geophones.

Throughout acquisition of the marine reflection seismic and the offshore-onshore, wide-angle seismic data, a threecomponent borehole seismometer was held clamped at a depth of $400 \mathrm{~m}$ in the Middle Basalt Formation in the Glyvursnes borehole.

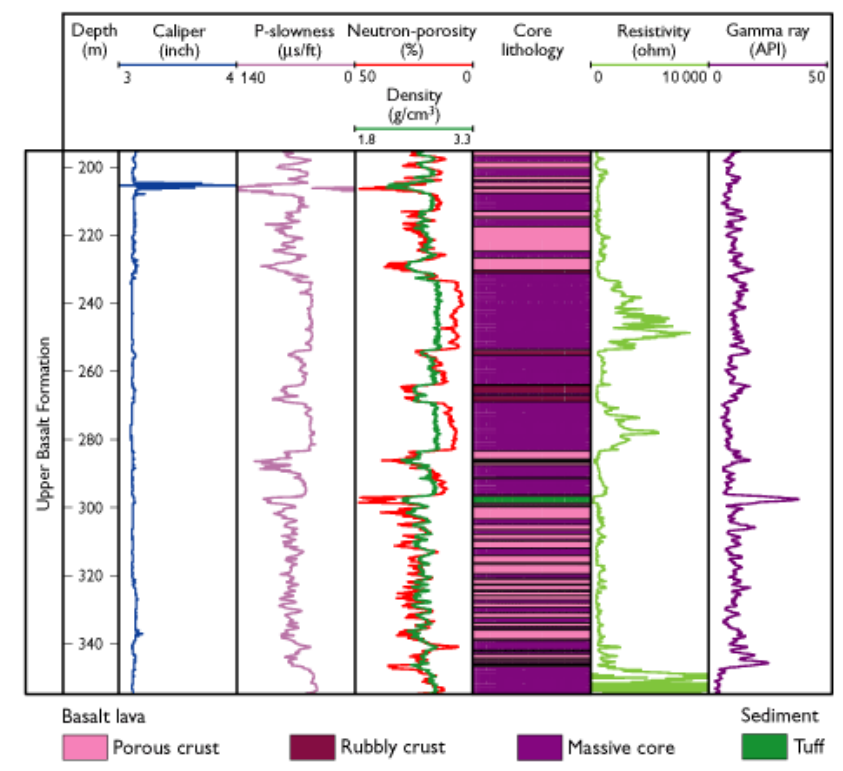

Fig. 4. Composite log from the Glyvursnes-1 well. Note the correlation between P-slowness (P-wave velocity) and density/neutron porosity that reflects the porosity-contrast between the porous crust and the massive core of the basalt flows (from Japsen et al. in press). 


\section{Future work}

A detailed analysis of seismic wave propagation through a typical Faroese basalt succession will be carried out using the logging carried out in 2002, ongoing laboratory work on the core and the seismic data acquired during the summer of 2003. With the sonic logging and the vertical VSP, a detailed vertical velocity profile will be obtained in the Glyvursnes-1 borehole and determine intrinsic and extrinsic attenuation/scattering of seismic waves in one dimension. By combining the two detailed fixed offset VSPs and variable offset with data registered at fixed depth, it is planned to address attenuation/scattering in two (three) dimensions. Using the multichannel seismic data and the autonomous seismic array it is planned to obtain two-dimensional and three-dimensional velocity distribution in a small area around the borehole. The multichannel surface seismic experiment is designed to analyse sub-critical and post-critical reflections from the basalt succession drilled at Glyvursnes, providing an image of structural continuity in the area.

\section{Perspectives}

Drilling of the new borehole at Glyvursnes and re-logging of Vestmanna-1 in combination with the extensive data set for the Lopra-1 well will give valuable new stratigraphic and petrophysical control of the Lower, Middle and Upper Basalt Formations on the Faroe Islands. The planned experiments will provide a link from hand-specimen scale, through the slightly larger averaging of borehole logs, to seismic scales ranging from high-resolution VSPs and multi-channel land arrays, to onshore-offshore shooting using wide-band airguns, to the truly long-period response of the basalt flows using teleseismic arrivals. The investigations will provide a unique data set and, hopefully, new understanding of the seismic and petrophysical properties of Faroe Islands basalts.

\section{Acknowledgements}

Thanks are due to the Sindri Group for permission to publish results from the Glyvursnes-1 well. SeiFaBa is funded collectively by all oil companies operating in the Faroe Islands sector (the Sindri Group).

\section{References}

Boldreel, L.O. \& Andersen, M.S. 1993: Late Paleocene to Miocene compression in the Faroe-Rockall area. In: Parker, J.R. (ed.): Petroleum geology of Northwest Europe: Proceedings of the 4th Conference, 1025-1034. London: Geological Society.

Grant, N., Bouma, A. \& McIntyre, A. 1999: The Turonian play in the Faroe-Shetland Basin. In: Fleet, A.J. \& Boldy, S.A.R. (eds): Petroleum geology of Northwest Europe: Proceedings of the 5th Conference, 661-673. London: Geological Society.

Japsen, P. et al. in press: Preliminary results of petrophysical and seismic properties of Faroes basalts (SeiFaBa project). In: Doré, A.G. \& Vining, B. (eds): Petroleum geology: North-West Europe and global perspectives: Proceedings of the 6th Petroleum Geology Conference. London: Geological Society.

Rasmussen, J. \& Noe-Nygaard, A. 1970: Geology of the Faroe Islands. Danmarks Geologiske Undersøgelse, I. Række 25, 142 pp.

Sørensen, A.B. 2003: Cenozoic basin development and stratigraphy of the Faroes area. Petroleum Geoscience 9, 189-207.

Waagstein, R. 1988: Structure, composition and age of the Faeroe basalt plateau. In: Morton, A.C. \& Parson, L.M. (eds): Early Tertiary volcanism and the opening of the NE Atlantic. Geological Society Special Publication (London) 39, 225-238

Waagstein, R. 1998: A geological field guide to the Palaeogene flood basalts of Suderoy, Faroe Islands. Danmarks og Grønlands Geologiske Undersøgelse Rapport 1998/30, 46 pp.

Waagstein, R., Boldreel, L.O. \& Andersen, C. 2003: An integrated petrophysical approach to the sub-basalt imaging problem using well logging data to link measurements from cores and seismic surface experiments. Geophysical Research Abstracts 5(09388), 2 pp.

White, R.S., Smallwood, J.R., Fliedner, M.M., Boslaugh, B., Maresh, J. \& Fruehn, J. 2003: Imaging and regional distribution of basalt flows in the Faroe-Shetland Basin. Geophysical Prospecting 51, 215-231.

\footnotetext{
Authors' addresses

P.J. \& R.W., Geological Survey of Denmark and Greenland, Øster Voldgade 10, DK-1350 Copenhagen K. E-mail: pj@geus.dk M.S.A., University of the Faroe Islands, Noatún 3, FO-100 Tórshavn, Faroe Islands. Present address: Geological Survey of Denmark and Greenland, Øster Voldgade 10, DK-1350 Copenhagen K.

L.O.B., Geological Institute, University of Copenhagen, Øster Voldgade 10, DK-1350 Copenhagen K, Denmark.

R.S.W., Bullard Laboratories, University of Cambridge, Madingly Road, Cambridge CB3 OEZ, UK.

M.W., Department of Earth Sciences, University of Oxford, Parks Road, Oxford OX1 3PR, UK.
} 